\title{
Prevalence of dental anomalies and bone alterations in children's panoramic radiographies
}

\author{
Prevalência das anomalias dentárias e alterações ósseas \\ em radiografias panorâmicas de crianças
}

\author{
Jéssica Costa REIS1 iD https://orcid.org/0000-0003-1089-0812 \\ May Anny Alves FRAGA 1 iD https://orcid.org/0000-0002-9323-0862 \\ Sérgio Lins DE-AZEVEDO-VAZ² iD https://orcid.org/0000-0001-5578-5309 \\ Maria Helena Monteiro de Barros MIOTTO² iD https://orcid.org/0000-0002-3227-7608 \\ Teresa Cristina Rangel PEREIRA ${ }^{2}$ iD https://orcid.org/0000-0001-6458-9465 \\ Danielle Resende CAMISASCA2 ID https://orcid.org/0000-0003-1193-2113
}

\begin{abstract}
Objective: To verify the prevalence of dental anomalies in terms of number, position and shape, and the presence of bone alterations, through analysis of panoramic radiographs. Methods: This study evaluated dental anomalies and bone alterations in children aged 6 to 12 years-old, detected on panoramic radiographies recorded in the radiographic database of the Federal University of Espírito Santo between 2012 and 2016. Clinical and demographic information were registered. Dental records were retrieved to obtain the medical history involving syndromes or other diseases that may interfere with the anomalies and alterations. Chi-square and exact Fischer's statistical tests were performed. Results: There were alterations in 83 out of 301 panoramic radiographs analyzed. There were 169 anomalies or alterations (mean of 2,04 1,38 anomalies/patient), involving 201 teeth. The most prevalent anomaly was tooth impaction (26.63\%), which affected the canines more frequently, followed by hypodontia (24.26\%), more often found in the second premolar, and both affected mostly females. Hyperdontia and radiolucent lesions showed the same prevalence (18.93\%), the most affected teeth were those of the anterosuperior region and the first mandibular molars, respectively. The least prevalent anomalies were dilaceration (7.69\%), taurodontism (2.37\%) and radiopaque lesions (1.18\%). Bone alterations were significantly more found in mandible and in the posterior region, which confirms the prevalence in the lower molars. Conclusion: Although there was no statistically significant difference regarding sex, there was a high prevalence of anomalies and alterations in our study population, which indicates the importance of its diagnosis by means of a panoramic x-ray examination.
\end{abstract}

Indexing terms: Panoramic radiography. Anodontia. Supernumerary tooth.

\section{RESUMO}

Objetivo: Verificar a prevalência das anomalias dentárias de número, posição e forma, além da presença de alterações ósseas, por meio de radiografias panorâmicas. Métodos: Levantamento das anomalias dentárias e alterações ósseas em crianças de 6 a 12 anos,

1 Universidade Federal do Espírito Santo, Curso de Odontologia, Departamento de Clínica Odontológica. Av. Marechal Campos, 1468, Maruípe, 29043-900, Vitória, ES, Brasil. Correspondence to: JC REIS. E-mail: <jessiica_costa@hotmail.com>.

2 Universidade Federal do Espírito Santo, Curso de Odontologia, Departamento de Clínica Odontológica. Vitória, ES, Brasil.

$\boldsymbol{\nabla} \nabla \boldsymbol{v}$

How to cite this article

Reis JC, Fraga MAA, DeAzevedo-Vaz SL, Miotto MHMB, Perreira TCR. Alterations in Panoramic Radiographies in Children. RGO, Rev Gaúch Odontol. 2020;68:e20200073. http://dx.doi.org/10.1590/1981-863720200005820180073 
com radiografia panorâmica registrada no Banco de Imagens Radiográficas da Universidade Federal do Espírito Santo nos anos de 2012 a 2016. Foram registradas informações clínico-demográficas referentes aos pacientes atendidos. As fichas clínicas foram recuperadas para obtenção da história médica de síndromes ou outras doenças que interfiram nas anomalias e alterações. Foram realizados os testes estatísticos qui-quadrado ou exato de Fischer. Resultados: Foram encontradas 83 radiografias panorâmicas que mostravam

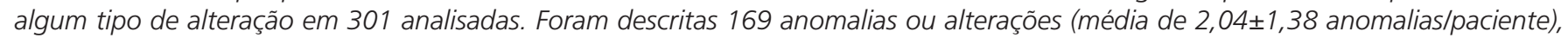
envolvendo 201 dentes. A anomalia mais prevalente foi a impactação (26,63\%) que afetou mais os caninos, seguida da hipodontia $(24,26 \%)$ que ocorreu mais em segundos pré-molares, em ambas o sexo feminino foi mais acometido. A hiperdontia e as lesões radiolúcidas tiveram a mesma prevalência (18,93\%), os dentes mais acometidos foram da região ântero-superior e os primeiros molares inferiores, respectivamente. As menos prevalentes foram dilaceração (7,69\%), taurodontia (2,37\%) e lesões radiopacas (1,18\%). As anomalias ósseas estavam significativamente mais em mandibula e na região posterior, o que confirma a prevalência em molares inferiores. Conclusão: Não houve diferença estatisticamente significativa em relação ao gênero. Mas houve alta prevalência de anomalias e alterações na população estudada, o que denota a importância do diagnóstico por meio desse importante exame complementar.

Termos de indexação: Radiografia panorâmica. Anodontia. Dente supranumerário.

\section{INTRODUCTION}

Dental anomalies can affect deciduous or permanent dentition and they may be classified according to their number (hypodontia and hyperdontia), shape (taurodontism and dilaceration), position (transposition and impaction), among others. Bone alterations can also develop in both dentitions and can be cystic, tumoral or idiopathic. These alterations, depending on their characteristics and size, can lead to major disorders in the quality of life of the family and the child $[1,2]$.

Frequency studies (prevalence and incidence) are very relevant due to genetic and ethnic variability. In addition, sample differences (age, sex, region, country) and diagnostic criteria are factors that indicate the need for various studies of this type [3-5].

Monitoring the development and eruption of teeth is very important for the early diagnosis of dental anomalies and consequently for dental planning of cases. The tests requested for detection of these alterations include detailed clinical examination and complementary exams, such as radiographies. Panoramic radiography is considered the gold standard for this purpose, because it offers a global view of the structures of the maxillomandibular complex in a single take, and besides, it is the most accepted radiography by children and requires a low radiation dose when compared to computed tomography and complete periapical scans [6-8].

To request a panoramic radiography for children in the age group of 6 to 7 years old is a very valid and prudent conduct for the diagnosis and treatment plan, even in mixed dentition, since the examination offers the opportunity to identify the position of unerupted teeth and their possible eruption site [9].
Dental anomalies and lesions of the gnathic bones in children can alter tooth eruption, lead to abnormal occlusion and, in some cases, the child's aesthetics and social life may be affected in the future. If early detected, these changes can be surgically or orthodontically treated, especially with interceptive orthodontics, thus reducing functional, psychosocial and financial problems [10]. In addition, panoramic radiography can be used as an initial complementary exam to check whether the chronology of tooth eruption is in line with the expected for the child's age [11]. Thus, this study aimed to verify the prevalence of dental anomalies in terms of number, position and shape, also to the presence of bone alterations, by means of panoramic radiography analysis from the radiographic database of the Federal University of Espírito Santo (UFES).

\section{METHODS}

This is a retrospective descriptive study in which, firstly, a survey was carried out considering cases of dental anomalies and pathological bone alterations in children aged from 6 to 12 years who underwent at least one panoramic radiography, necessarily registered in the image database of the Dental School (extra class project of the UFES Dental School) from 2012 to 2016. The research was approved by the ethics committee prior to starting data collection, under the protocol 1.871.219.

Patients belonging to the age group analyzed and who had a panoramic radiography taken during the study period were included. Cases were excluded when the quality of the radiographic examination was deficient, when the possibility of a previous extraction could not be excluded for hypodontia cases, or exams were from syndromic patients and the alterations or anomalies involved third molars. 


\section{Radiographic analysis}

Among the dental anomalies, we considered number changes (hypodontia or missing teeth, hyperdontia or supernumerary teeth), changes in position (transposition, impaction), as well as changes in the shape of the teeth (taurodotism, dilaceration).

Hypodontia was considered when the permanent tooth correspondent to the erupted deciduous was absent; when only the permanent was absent, and clinical information was used to confirm whether it was true hypodontia or tooth extraction. Hyperdontia was found in exams of patients who had an excess number of permanent teeth, such as in cases of mesiodens. Transposition was observed when two permanent teeth had switched positions in the arch. Impaction was considered when there was an included or semi-included tooth with a complete root and a physical barrier. Supernumerary teeth were not considered impacted. Cases in which the floor of the pulp chamber reached at least half of the root level were admitted as taurodontism. Roots reaching at least an inclination angle of $45^{\circ}$ were considered as dilacerations.

Among the pathological bone alterations, radiolucent, radiopaque or mixed cystic images were considered, and they could be associated or not with the tooth, as well as tumoral or cemento-osseous images, which could also be radiolucent, radiopaque or mixed, associated or not with the tooth. Possible diagnostic hypotheses were raised for each case, which may include developmental cysts, inflammatory cysts, bone cysts, odontogenic cysts, odontogenic tumors or cemento-osseous dysplasia.

Clinical and demographic information was also collected, such as: sex, age, location of the lesion or abnormality (maxilla, mandible, involved tooth and side of the lesion), in addition to the number of affected teeth.

The images were analyzed by two observers in consensus, in case of doubt a third observer (a professor, specialist in radiology) was consulted. Every two days, groups of 30 images were analyzed, thus avoiding the physical fatigue of the observers during the readings. The panoramic digital radiographs were analyzed on an LCD computer screen, at least 15 inches, in the Windows image viewer software, in a dark room.

For the calibration of observers, a representative case of each anomaly was selected and displayed in a situation similar to the environment for analyzing radiographic changes. To calibrate the observers, $20 \%$ of the sample was selected at the beginning of the analysis.

The panoramic radiographs were analyzed according to the protocol applied in the discipline of Interdisciplinary Clinical Stage I of UFES, in which the adjacent bones were first observed, looking for changes in the structures (teeth in ectopic positions, cystic and tumoral lesions), then the tooth counting was performed to identify missing and supernumerary teeth. And finally the analysis of each tooth, in the crown-apex direction, following the order of the quadrants (upper right, upper left, lower left, lower right quadrant).

\section{Clinical analysis}

In a second phase, the cases were separated into two categories: unchanged and altered. In cases with changes detected, the medical files of patients treated at the different clinics that receive children from the UFES Dental School were retrieved to complement data. In cases of doubt about the records, telephone contact was made with the patient's family to clarify the situation.

The analysis of the clinical information was focused on the changes found on the radiograph. It was observed whether the patient presented alterations in his medical history that could be compatible with the presence of genetic syndromes or other diseases that interfere with the presence of the abnormalities and alterations found. Furthermore, the physical examination including the odontogram and the procedures performed were analyzed in order to observe whether the absences were true or if there was previous extraction or decompression treatment in injuries, as well as if there were other signs and symptoms that could be related to the anomaly or bone alteration observed.

\section{Statistical analysis}

The data collected were tabulated in the Excel Software (Windows) and the statistical analysis was performed in the SPSS 20.0 Software. The statistical analysis was descriptive, using means and proportions. A correlation of the variables analyzed was also performed in relation to the presence of dental anomalies and pathological bone alterations, as well as between each of the anomalies and alterations separately, using the 
Chi-square or Fischer's exact test. A p-value $<0.05$ were considered significant.

\section{RESULTS}

A total of 2958 panoramic radiographs were taken between the years 2012 and 2016. The exams of children aged between 6 and 12 years old on the date of the exam were selected for the study. A total of 301 radiographs were selected and analyzed - $170(56.47 \%)$ of them from male patients and 131 (43.53\%) from female.

In 2016, 141 radiographs were identified, while in 2015 there were 52, 67 in 2014, 39 in 2013 and 2 in 2012.
There was a greater number of panoramic radiographs in 2016. A difference between sex and presence of dental anomalies/bone alterations was also identified when comparing the years 2012-2014 with the years 2015-2016, and in the recent years the presence of boys without dental anomalies or bone alterations was more frequent (table 1).

Out of the 301 radiographs analyzed, 86 showed dental anomalies and bone alterations, both in the primary and permanent dentition. The access to clinical information from a secondary source (dental files) was possible in 56 cases. Herein, 3 exams were excluded because the patients presented an oddly high number of changes, one of them

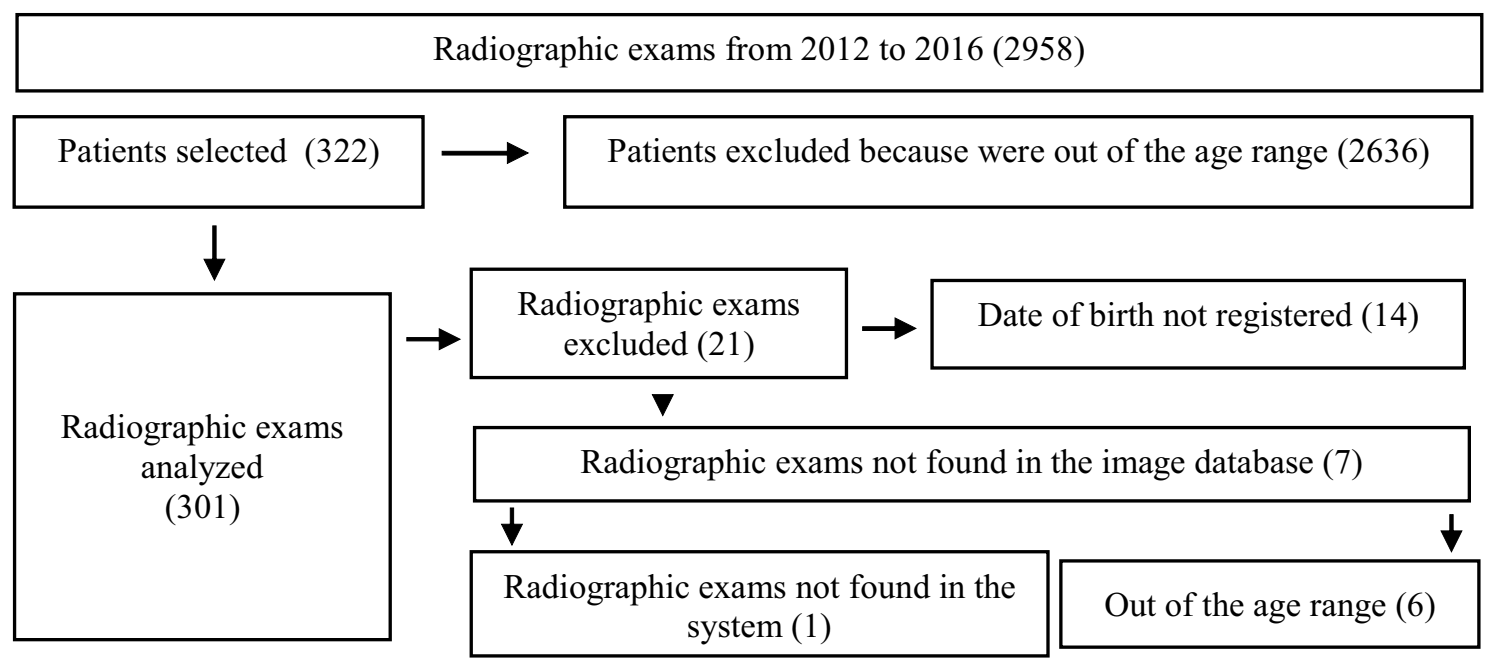

Figure 1. Flowchart illustrating the selection of radiographic exams in the image database.

Table 1. Distribution of radiographs in the years 2012-2014 and 2015-2016 in terms of sex, and the presence or absence of dental anomaly and bone alteration.

\begin{tabular}{|c|c|c|c|c|}
\hline Variable & & $\begin{array}{c}2012-2014 \\
n(\%)\end{array}$ & $\begin{array}{c}2015-2016 \\
n(\%)\end{array}$ & p-valor ${ }^{*}$ \\
\hline \multirow{4}{*}{ Sex } & Male & 53 & 117 & \multirow{3}{*}{0.069} \\
\hline & & $(49.0 \%)$ & $(60.6 \%)$ & \\
\hline & Female & $\begin{array}{c}55 \\
(51.0 \%)\end{array}$ & $\begin{array}{c}76 \\
(39.4 \%)\end{array}$ & \\
\hline & Total & 108 & 193 & 301 \\
\hline \multirow{4}{*}{ Presence or absence of dental anomaly or bone alteration } & Presence & 40 & 43 & \multirow{3}{*}{0.007} \\
\hline & & $(37.0 \%)$ & $(22.3 \%)$ & \\
\hline & Absence & $\begin{array}{c}68 \\
(63.0 \%)\end{array}$ & $\begin{array}{c}150 \\
(77.7 \%)\end{array}$ & \\
\hline & Total & 108 & 193 & 301 \\
\hline
\end{tabular}

*Fisher's exact test. 
with a syndrome confirmed by the parents, which ended up in a total of 83 radiographs with anomalies or alterations.

The mean age of patients with dental anomaly was 9.4 years, ranging from 6 to 12 years old. The sample was divided into 39 boys (46.98\%) and 44 girls (53.02\%).

Thus, dental anomalies or bone alterations were found in 83 patients, involving 201 teeth, on 301 radiographs. There were 22 patients with hypodontia (7.3\%), 21 patients with hyperdontia (6.9\%), no patients showed transposition, 26 patients with tooth impaction (8.6\%), 2 patients with taurodontism (0.6\%), 10 patients with root dilaceration (3.3\%), 25 patients with radiolucent lesions (8.3\%) and 2 patients with radiopaque lesions $(0.6 \%)$. It is worth to note that the same patient could present more than one anomaly or alteration.

Tooth anomalies and bone alterations could be distributed as follows: 41 cases of hypodontia (24.0\%), 32 cases of hyperdontia (19.0\%), 13 of root dilaceration (8.0\%), 4 of taurodontism (2.0\%), 32 images of radiolucent lesions (19.0\%) and 2 of radiopaque lesions (1.0\%), 45 of tooth impaction (27.0\%) and no transposition cases. There were 169 changes and anomalies in total, with an average of 2.04 anomalies / changes per patient and standard deviation of 1.38 .

There were also 22 patients with dental agenesis and a total of 41 affected teeth. The highest prevalence of agenesis was in the second premolars ( 23 out of 41 , $56.10 \%)$. Eight lateral incisors were affected (19.51\%), with the left upper lateral incisor being more affected with 5 teeth. Eight central incisors (19.51\%) were absent, affecting only the mandible, and there was an absence of the first and second lower molars in one case each (2.44\%). There was a prevalence in girls (59.09\%) for this tooth anomaly. There was no variation regarding the side, with 20 cases $(48.78 \%)$ on the right side and 21 (51.22\%) on the left side. In the maxilla, 18 cases (43.90\%) were identified and 23 (56.10\%) in the mandible. In the upper right quadrant, there were $8(19.51 \%)$ agenesis, 10 (24.39\%) in the upper left, $11(26.83 \%)$ in the lower left, and $12(29.27 \%)$ in the lower right.

The study demonstrated hyperdontia in 21 patients and 32 supernumerary teeth. The highest prevalence was in the anterior maxilla (14 out of 32,43.80\%), being 6 cases between central and lateral incisors, 6 cases between lateral incisors and canine and in 2 cases they were located in the apical region of central incisors. There were 12 cases of mesiodens (12 out of $32,37.50 \%$ ) of varying sizes and shapes. In the anterior mandible there were 4 cases of supernumeraries (4 out of $32,12.50 \%$ ). Finally, there was 1 supernumerary in the right posterior region (between premolar and molar) and only one was found in the primary dentition. These cases were more prevalent in boys (57.14\%).

There was a variation related to the side in hyperdontia, with 15 cases in the midline $(46.88 \%), 9$ in the right side $(28.12 \%)$ and 8 in the left side $(25 \%)$. Most cases occurred in the maxilla, with 27 cases (84.37\%), while in the mandible there were only 5 (15.63\%). Regarding the quadrants, there were 6 cases in the upper right quadrant $(18.75 \%), 6$ in the upper left $(18.75 \%), 3$ in the lower right $(9.37 \%), 2$ in the lower left $(6.25 \%)$, and 15 in the midline $(46.88 \%)$.

In 26 patients there was a total of 45 impacted teeth, with an average of 1.73 teeth per child. The highest prevalence of impaction was in the upper canines (19, $42.22 \%)$. There were 7 upper central incisors affected $(15.55 \%), 5$ lower canines $(11.11 \%)$ and 4 upper lateral incisors $(8.89 \%)$. It was observed that the second premolars were affected 3 times, as well as the first and second molars (6.67\%). The first lower left premolar was affected once $(2.22 \%)$. There was a prevalence in girls $(57.70 \%)$ and no significant variation regarding the side. Also, the maxilla was more affected, counting with 32 cases $(71.11 \%)$. Concerning the quadrants, the difference was irrelevant, with a higher number of cases in the upper right quadrant (40\%).

Only 2 patients presented taurodontism, with 4 teeth showing this pulp chamber alteration. The lower permanent second molars represented $(50 \%)$ of the sample, with severe taurodontism. The lower deciduous first molars represent the other half and showed moderate alteration. Only girls were affected, and the right side was affected in the same way as the left side. The mandible was affected in all cases, with no cases being observed in the maxilla.

Ten patients showed root dilaceration with 13 teeth presenting the anomaly. The first molars were the most affected $(6,46.15 \%)$. The upper incisors (both central and right lateral incisor) were affected once each (23.1\%), the upper and lower left canines were also affected once (15.4\%). Dilaceration also occurred in the upper right second premolar and the lower left first premolar. 
Regarding sex distribution, half of the sample were boys and the other half girls. In the comparison between the sides, the right side presented 6 cases $(46.15 \%)$ and the left side 7 (53.85\%), with no significant difference. The maxilla had more cases than the mandible, $9(69.23 \%)$ and $4(30.77 \%)$ respectively. In the upper right quadrant, there were 4 cases (30.77\%), 5 in the upper left (38.46\%), 2 in the lower left (15.38\%) and 2 in the lower right (15.38\%).

In terms of radiolucent lesions, 25 patients presented this type of lesion. Thirty-two images of radiolucent lesions involving 64 teeth were observed. The first lower molars (17 out of $64,26.56 \%$ ) were the most affected by this type of bone alteration, followed by the lower central incisors $(8,12.5 \%)$, the lower lateral incisors $(7,10.94 \%)$, and the lower canines $(6,9.39 \%)$. The lower second premolars had the same number of cases of lower deciduous second molars $(5,7.81 \%)$. The lower first premolars were affected in 4 cases $(6.25 \%)$. The amount of cases was the same in the upper central incisors and upper left canines $(3,4.69 \%)$. Also, the upper lateral incisors, lower second molars and other teeth registered the same number of cases $(2,3.12 \%)$. Besides it, a higher prevalence was found in girls (56\%).

There was no considerable difference between the sides, with the right side showing 31 cases (48.44\%). The maxilla was less affected with only 10 cases (15.62\%), while the mandible had 54 cases (84.38\%). As for the quadrants, the lower right showed the highest prevalence, with 29 cases (45.32\%). Twelve hypotheses of periapical inflammatory lesions were raised in permanent teeth and 5 in deciduous teeth, as well as 5 hypotheses of dentigerous cyst, with 2 of them confirmed by histopathological reports, and 4 teeth associated with pericoronal follicles. The cases of calcifying odontogenic cyst and unicystic ameloblastoma were confirmed by histopathological report as well. In two patients, there was duplicity of diagnostic hypothesis,

Table 2. Distribution of dental anomalies and bone alterations in relation to sex, side, arch and region.

\begin{tabular}{|c|c|c|c|c|c|c|c|}
\hline \multirow[b]{2}{*}{ Variable } & & \multicolumn{2}{|c|}{ Dental anomaly } & \multicolumn{3}{|c|}{ Bone alteration } & \multirow[b]{2}{*}{ p-valor ${ }^{*}$} \\
\hline & & $\begin{array}{c}\text { Yes } \\
n(\%)\end{array}$ & $\begin{array}{c}\text { No } \\
\text { n (\%) }\end{array}$ & $\mathrm{p}$-valor ${ }^{*}$ & $\begin{array}{c}\text { Yes } \\
n(\%)\end{array}$ & $\begin{array}{c}\text { No } \\
\mathrm{n}(\%)\end{array}$ & \\
\hline Sex & Female & $\begin{array}{c}39 \\
(55.7 \%)\end{array}$ & $\begin{array}{c}7 \\
(53.9 \%)\end{array}$ & 1.00 & $\begin{array}{c}14 \\
(60.9 \%)\end{array}$ & $\begin{array}{c}32 \\
(53.3 \%)\end{array}$ & 0.62 \\
\hline \multirow{2}{*}{ Side } & Left & $\begin{array}{c}17 \\
(24.3 \%)\end{array}$ & $\begin{array}{c}4 \\
(30.8 \%)\end{array}$ & \multirow{2}{*}{0.85} & $\begin{array}{c}7 \\
(30.5 \%)\end{array}$ & $\begin{array}{c}14 \\
(23.3 \%)\end{array}$ & \multirow{2}{*}{0.61} \\
\hline & Bilateral & $\begin{array}{c}39 \\
(55.7 \%)\end{array}$ & $\begin{array}{c}7 \\
(53.8 \%)\end{array}$ & & $\begin{array}{c}13 \\
(56.5 \%)\end{array}$ & $\begin{array}{c}33 \\
(55 \%)\end{array}$ & \\
\hline \multirow{2}{*}{ Jaw bone } & Mandible & $\begin{array}{c}19 \\
(27,1 \%)\end{array}$ & $\begin{array}{c}13 \\
(100 \%)\end{array}$ & \multirow[t]{2}{*}{ a } & $\begin{array}{c}17 \\
(74 \%)\end{array}$ & $\begin{array}{c}15 \\
(25 \%)\end{array}$ & \multirow[t]{2}{*}{$<0.0001$} \\
\hline & Both & $\begin{array}{c}13 \\
(18.6 \%)\end{array}$ & 0 & & $\begin{array}{c}3 \\
(13 \%)\end{array}$ & $\begin{array}{c}10 \\
(16.7 \%)\end{array}$ & \\
\hline \multirow[t]{3}{*}{ Region } & Anterior & $\begin{array}{c}35 \\
(50 \%)\end{array}$ & $\begin{array}{c}3 \\
(23.1 \%)\end{array}$ & \multirow[t]{3}{*}{ A } & $\begin{array}{c}5 \\
(21.7 \%)\end{array}$ & $\begin{array}{c}33 \\
(55 \%)\end{array}$ & \multirow[t]{3}{*}{0.01} \\
\hline & Both & $\begin{array}{c}15 \\
(21.4 \%)\end{array}$ & 0 & & $\begin{array}{c}5 \\
(21.7 \%)\end{array}$ & $\begin{array}{c}10 \\
(16.7 \%)\end{array}$ & \\
\hline & Posterior & $\begin{array}{c}20 \\
(28.6 \%)\end{array}$ & $\begin{array}{c}10 \\
(76.9 \%)\end{array}$ & & $\begin{array}{c}13 \\
(56.6 \%)\end{array}$ & $\begin{array}{c}17 \\
(28.3 \%)\end{array}$ & \\
\hline
\end{tabular}

Note: $\mathbf{a}$ - it was not possible to calculate due to the small number of cases in each category. ${ }^{*}$ Chi-square or Fisher's exact test. 
Table 3. Distribution of each dental anomaly/bone alteration found in relation to the variables sex, side, arch and region.

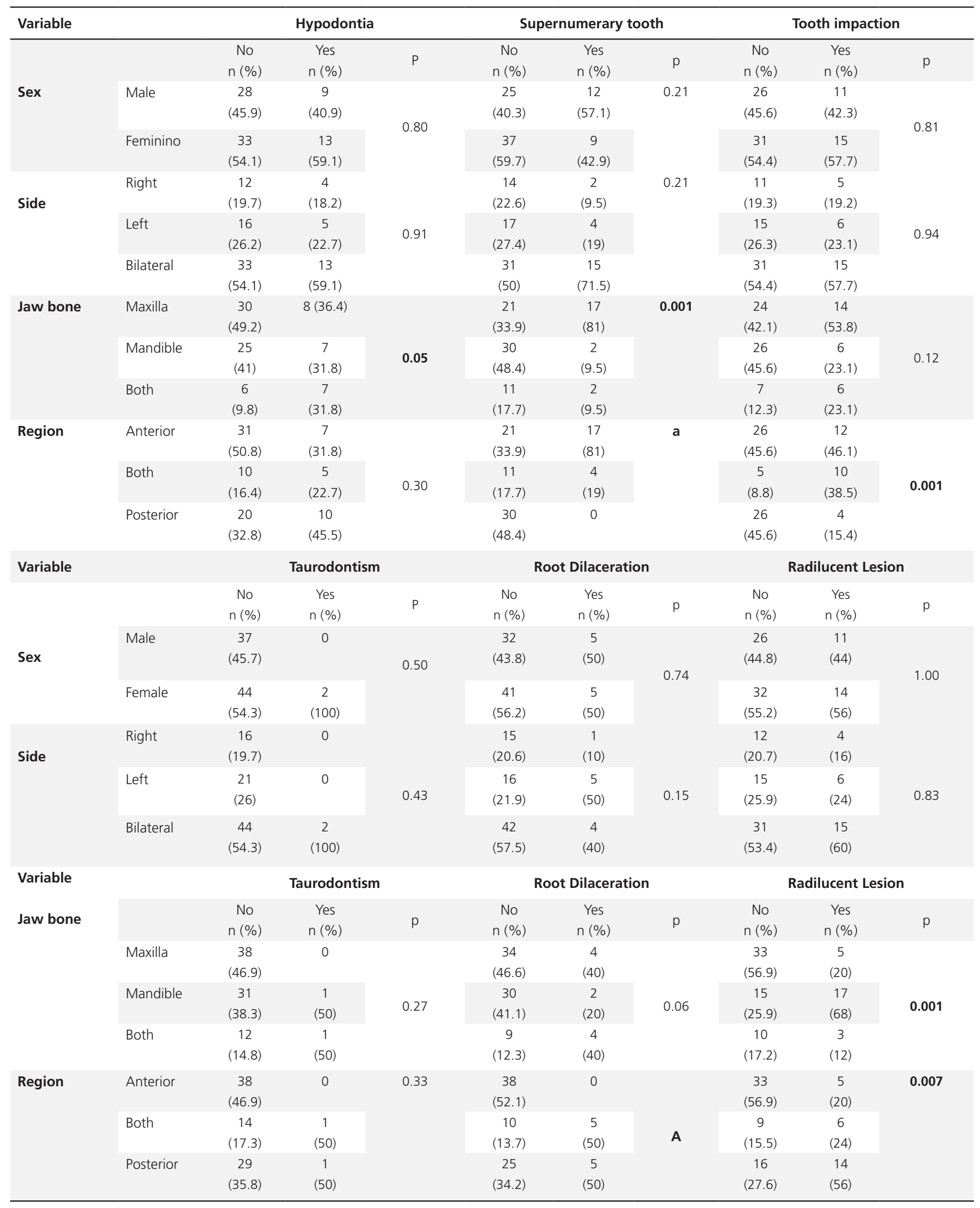

Note: $\mathbf{a}$ - it was not possible to calculate due to the small number of cases in each category. ${ }^{*}$ Chi-square or Fisher's exact test. 
one lesion with a report suggestive of an odontogenic cyst or cicatricial lesion and the other suggestive of an adenomatoid odontogenic tumor or dentigerous cyst.

The distribution of patients with radiolucent lesions according to age occurred as follows: in the 6 and 7-yearold patients there were 2 radiolucent lesions for each age group, in the 8-year-old patients there were 4 lesions, in the 9 and 11-year-old groups, 3 lesions in each group. Whilst in 10-year-old patients, there were 11 radiolucent lesions, the highest prevalence found.

Radiopaque lesions occurred in 2 patients and 2 teeth. One case involved the lower left first molar and the other case involved the lower left canine. The right side was affected once, as well as the left side. The maxilla was not affected, being the mandible the only one affected. The lower left quadrant had 1 case and the lower right 1 case. The diagnostic hypotheses for radiopaque lesions were constructed in the same way as for radiolucent lesions, in both cases the most likely hypothesis was idiopathic osteosclerosis.

\section{Correlation between variables}

There was a positive correlation between the presence of bone alterations in the mandible $(p<0.0001)$ and in the posterior region ( $p=0.01$ ) (table 2 ). Regarding dental anomalies, when analyzed one at a time, a positive correlation was observed between hypodontia and the occurrence in isolated arches, which means that it hardly occurs in both arches concurrently $(p=0.05)$. The supernumerary teeth occurred significantly more often in the maxilla ( $p=0.001$ ) (table 3 ). It was observed that the tooth impaction was significantly more present in the anterior region $(p=0.001)$. As for bone alterations, radiolucent lesions were significantly more frequent in the mandible $(p=0.001)$ and in the posterior region $(p=0.007)$ (table 3).

\section{DISCUSSION}

There was a significant increase in the number of panoramic radiographs in the years 2015 and 2016, characterizing $64.12 \%$ of the sample of the entire study. This profile has changed probably due to a research project that raised the request for panoramic radiographs mainly for boys aged 8-9 years, who were the focus of the research carried out at the institution in this period, besides to a new protocol adopted at the dental clinic. It is worth to mention that there was also an increase in requests for radiographs in general after 2014, period in which a radiology technician has been hired and one of the main duties was to perform panoramic radiographs.

Panoramic radiographs are usually requested for children only when a dental abnormality or bone alteration is suspected, which would lead to an increased prevalence of lesions. When it started to be requested by routine, there was a significant decrease in the prevalence of injuries, when compared to previous years (2012-2014). Panoramic radiography for this age group can be ordered to check the eruption chronology and supervise the space, to minimize or avoid orthodontic treatment. This exam is also important to observe the early loss of deciduous teeth, diastemas (caused by mesiodens) and canine impaction, which were anomalies detected in this study [7].

The results indeed demonstrate a high prevalence of dental anomalies and bone alterations in children treated at the UFES Dental School (27.6\%), a finding corroborated with other studies $[1,12,13]$.

Hypodontia was found in 22 out of 301 (7.3\%) radiographs analyzed, which is higher than the prevalence found by some authors [14-16], but very similar to the findings of other authors $[3,11,17]$. This dental abnormality rarely affected both jaws concurrently $(p=0.05)$ and often presented bilaterally in the same arch, even though there were no statistically significant results. Furthermore, the most affected teeth were the second premolars followed by the lateral incisors, results that corroborate with Fekonja [11].

In the first genetic study addressing familial hypodontia, the author identified a defective molecule in the formation of second premolars, which are the teeth most affected according to the literature and our study. The mutation in the MSX1 gene was related to dental agenesis that occurred in several members of the family studied [18]. Other authors also found few cases of hypodontia in both arches, with a higher prevalence in female patients, data similar to our findings. They also found a greater number of hypodontia in the maxilla [17].

For hyperdontia, there was a prevalence of $6.9 \%$ (21 out of 301), a number higher than that found in the literature $[1,11,13-17,19-21]$. The high prevalence of hyperdontia may be due to the fact that panoramic 
radiography is often requested to observe the tissues adjacent to the teeth in the surgical planning of extraction of supernumeraries. The extraction of these elements is important because it prevents prolonged tooth retention and possible alterations in occlusion. Such treatment is offered free of charge to the population by Oral and Maxillofacial Surgery and Interdisciplinarity in Child Patients at UFES, and the demand for this type of surgery is relatively high, justifying the high prevalence found.

The most prevalent supernumerary teeth found were mesiodens, the same result described by some authors $[13,19,21]$, though other studies have found a higher prevalence among premolars $[1,20]$. Supernumerary teeth are more common in male patients, same as observed in our study $[11,16,19,21]$. There were significantly also more supernumerary teeth in the maxilla, which is also stated in the literature $[13-15,19,21]$.

Regarding number of anomalies (hypodontia and hyperdontia), an Indian group29 found a higher prevalence of hyperdontia, specifically mesiodens. What differs from the result from our study, probably due to the large age group used in the Indian study (10-70 years). On the other hand, Gupta et al. [22], also from India, found a higher prevalence of hypodontia, the same found in our study, even though it differs from our findings concerning the most affected tooth, since they show a higher prevalence in the upper lateral incisors.

The total number of impacted teeth among the 26 affected patients was 45 , with a mean of 1.73 per child. This average was higher than that found in the literature [23]. The prevalence of tooth impaction in the current study was $8.6 \%$ (26 out of 301 ) being the highest among the anomalies analyzed, a result similar to that found by other authors [16] (13.7\%), but in disagreement with other studies $[1,3]$ that found proportions of $21.4 \%$ and $31.52 \%$. This dental anomaly affected more girls than boys, which corroborates with the literature $[11,16,23]$.

Tooth impaction was the anomaly more significantly found in the anterior region, i.e. little found in the posterior region or in both regions. This reaffirms that the teeth most affected by impaction were the upper canines, upper central incisors and lower canines, all considered anterior teeth. Some studies reported that the teeth most affected were canines $[1,23]$, as in the present study.

Girondi et al. [3] analyzed 533 panoramic radiographs of patients aged 12 to 25 years, an age group in which it is already possible to predict or diagnose impaction or eruption of third molars. In agreement with the current literature, the authors found that lower and upper third molars are more affected by impaction. Nevertheless, in the age group of our study, it is not possible to determine third molars impaction, since at 12 years of age these teeth are expected to be close to Nolla stage 4 for boys and close to or Nolla stage 5 for girls. In other words, 2/3 of the complete crown for boys and almost complete crown for girls [24].

Researchers show a low prevalence of transposition, usually found in the maxilla, between the lateral incisors and canine $[1,3,16]$. The first study which assembled a large sample of mandibular transposition, described an association between dental agenesis and microdontia of the affected teeth, which generates great repercussion in the dental arch, but still considered transposition a rare alteration, both in the maxilla and in the mandible [25]. Hence, the absence of cases in the present study is supported by the literature.

Taurodontism was the dental anomaly of lower prevalence, about $0.6 \%$, as well as the results of other Brazilian studies [3,12,16], an Arab [13] and a Slovenian [11] study. The small number of cases of this anomaly in our study might be explained by its greater frequency in other populations, such as Eskimos, and those born in Central America and Australia [3].

A study carried out in the extreme north of Brazil showed a $27.2 \%$ prevalence of taurodontism, which is much higher than our findings and those from the literature. Taurodontism has as one of the possible causes the invagination of the Hertwig's epithelial root sheath, which is specified by a genetic determination, thus can differ according to the country region [4]. Another explanation is that the criteria used by the authors were not very strict for the determination of this dental anomaly.

The prevalence of root dilaceration found was $3.3 \%$, which is corroborated by the literature $[4,5,12,16]$. The diagnosis of this anomaly is essential, because depending on the degree of the root dilaceration it can generate complications for orthodontic treatment and difficulty in extraction and endodontics treatment of the affected teeth, which leads to the need for accurate orthosurgical planning.

A higher prevalence of root dilaceration in first molars was found, which is in agreement with that found 
by Menini et al. [12], besides, there were more cases in the upper arch similar to results published by Shokri et al. [5].

One study analyzed medical files of 57 patients aged up to 16 years who had a final diagnosis of benign cystic lesions. They found a very similar prevalence to our data, regarding the presence of bone alterations (dentigerous cyst, periapical lesion or granuloma and calcifying odontogenic cystic) and the mandible as the most affected bone [2].

Another study also found results similar to our data regarding radiolucent bone alterations (33 images compatible with radiolucent cysts, mostly inflammatory), though the maxilla was the most affected, and more prevalent in the upper canines, different from our findings [19]. In a study carried out in Minas Gerais - Brazil [26], using panoramic radiographs of children, the authors observed that $22.68 \%$ of the sample presented periapical lesions, a prevalence much higher than that from our study (5.64\%).

The greater occurrence of radiolucent bone alterations in children aged around 10 years was also ratified by Tkaczuk et al. [2]. It is believed that at this age, the eruption or impaction of most permanent teeth has already occurred, and besides it is an age of better acceptance of dental treatments, mainly the orthodontic ones. This fact consequently makes it possible to perform the panoramic examination and diagnose the bone lesions.

The radiolucent bone alterations were significantly more observed in the mandible and in the posterior region, which confirms the greater involvement of the lower first molars. As it is the first permanent tooth to erupt, it is commonly exposed to caries factors for a longer time and because it is still considered as a deciduous tooth by family members, it is the tooth more susceptible to developing caries with pulp involvement and later lesions or periapical granulomas. Interestingly, these changes in the region of the first molar were precisely the most prevalent in this study $[19,27]$.

Shokri et al. [5] published that dental anomalies and bone alterations were found in $29 \%$ of the studied population, corroborating with our results of $27.57 \%$. The same does not occur regarding location, since the current study found a higher prevalence in the mandible $52.23 \%$, while Shokri et al. [5] found $54.42 \%$ in the maxilla. This distinction possibly happened because the author did not study the prevalence of bone injuries. Comparing the results of the present study with the results of the aforementioned study, it is observed that in hypodontia we found $24.26 \%$ vs $15.88 \%$ from them; in hyperdontia $18.93 \%$ vs $6.76 \%$; in transposition $0 \%$ vs $0.68 \%$; in tooth dilaceration $7.69 \%$ vs $21.11 \%$; taurodontism $2.36 \%$ vs $9.29 \%$; dental impaction $26.62 \%$ vs $44.76 \%$. The observed prevalence differences can be justified by the heterogeneities of the sample, age and ethnicity, since this is an Iranian study.

Bekiroglu et al. [28] found more expressive results, because $43.28 \%$ of the sample aged 4 to 12 years old had dental anomalies and bone alterations, since they consider tooth absence as a pathology. The results of the study corroborate those of our study, as they found a considerable number of children affected by hyperdontia $4.35 \%$, impacted teeth $1.52 \%$ and radiolucent lesions $1.52 \%$ (mainly of inflammatory origin).

Diagnosing these bone alterations and dental anomalies at an early stage can lead to a better prognosis for the patient, avoiding the complications that occur as a result of these development issues. Therefore, it is understood the value of inserting the request for panoramic radiography as a protocol for the care of pediatric dentists and clinicians (from the private and public services) for individuals aged $7-8$ years [29].

\section{CONCLUSION}

A positive correlation was observed between the presence of radiolucent lesions in the mandible in the posterior region and most were of inflammatory origin. The supernumerary teeth were more present in the maxilla, while a correlation of tooth impaction with the anterior region was observed, probably due to the impossibility of evaluating third molar impaction in the studied age group. There was no statistically significant difference in the study regarding gender. Nevertheless, there was a high prevalence of dental anomalies and bone alterations (27.6\%) in our study population, which denotes the importance of early diagnosis of these injuries.

It is concluded that the association of clinical data with panoramic radiography was of substantial importance to determine the final diagnosis, especially in cases of hypodontia, hyperdontia and bone alterations. The search for this correct and early diagnosis leads to the establishment of adequate interdisciplinary treatment, which can reduce or even eliminate the further complications of dental anomalies and bone alterations. 
Collaborators

JC REIS - DDS. Contribution: Effective scientific and intellectual participation for the study; study design, data interpretation; preparation and draft of the manuscript; critical review and final approval. MAA FRAGA - DDS, MSc. Contribution: Effective scientific and intellectual participation for the study; data interpretation; critical review and final approval. SL DE-AZEVEDOVAZ - DDS, PhD. Contribution: Effective scientific and intellectual participation for the study; data acquisition, data interpretation; critical review and final approval. MHMB MIOTTO - DDS; PhD. Contribution: Effective scientific and intellectual participation for the study; data interpretation; critical review and final approval. TCR PEREIRA - DDS, PhD. Contribution: Effective scientific and intellectual participation for the study; study design, data interpretation; critical review and final approval. DR CAMISASCA - DDS; PhD. Contribution: Effective scientific and intellectual participation for the study; study design, data acquisition, data interpretation; preparation and draft of the manuscript; critical review and final approval.

\section{REFERENCES}

1. Pedreira FRO, Carli ML, Pedreira RPG, Ramos PS, Pedreira MR, Robazza CRC, et al. Association between dental anomalies and malocclusion in Brazilian orthodontic patients. Int J Oral Sci. 2016; 58(1):75-81. http://dx.doi.org/10.2334/ josnusd.58.75

2. Tkaczuk AT, Bhatti M, Caccamese JF, Ord RA, Pereira KD. Cystic Lesions of the Jawin Children a 15-Year Experience. JAMA Otolaryngol Head Neck Surg. 2015;141(9):834-9. http://dx.doi.org/10.1001/jamaoto.2015.1423

3. Girondi JR, Fenyo-Pereira M, Campos PSF, Panella J. Estudo da prevalência das anomalias dentárias de desenvolvimento em dada população com o uso de radiografias panorâmicas. Rev Odontol da UNICID. 2006;18(1):15-21.

4. Goncalves-Filho AJ, Moda LB, Oliveira RP, Ribeiro AR, Pinheiro JJ, Alver-Junior SM. Prevalence of dental anomalies on panoramic radiographs in a population of the state of Pará, Brazil. Indian J Dent Res. 2014;25:648-52. http://dx.doi. org/10.4103/0970-9290.147115

5. Shokri A, Poorolajal J, Khajeh S, Faramarzi F, Kahnamou HM. Prevalence of dental anomalies among 7- to 35-yearold people in Hamadan, Iran in 2012-2013 as observed using panoramic radiographs. Imaging Sci Dent. 2014;44:7-13. http://dx.doi.org /10.5624/isd.2014.44.1.7

6. Borba GVC, Borba Júnior JC, Pereira KFS, Silva PG. Levantamento da prevalência de agenesias dentais em pacientes com idade entre 7 e 16 anos. RGO, Rev Gaúch Odontol. 2010;58(1):35-9.

7. Gartner CF, Goldenberg FC. A importância da radiografia panorâmica no diagnóstico e no plano de tratamento ortodôntico na fase da dentadura mista. Rev Odonto.
2009;17(33):102-9. http://dx.doi.org/10.15603/2176-1000/ odonto.v17n33p102-109

8. Beluzzo LM, Kanashiro LK, Angelieri F, Sannomiya EK. Emprego da radiografia panorâmica no cotidiano clínico do(a) odontopediatra. Rev Odonto. 2007;15:17-27. http://dx.doi. org/10.15603/2176-1000/odonto.v15n30p17-26

9. Oliveira MMN, Correia MF, Barata JS. Aspectos relacionados ao emprego da radiografia panorâmica em pacientes infantis. Rev Fac Odontol Porto Alegre. 2006;47(1):15-9. http://dx.doi. org/10.22456/2177-0018.2110

10. Sharma G, Johal AS, Liversidge HM. Predicting Agenesis of the Mandibular Second Premolar from Adjacent Teeth. PLOS ONE. 2015;10(12):1-8. http://dx.doi.org/10.1371/journal.pone. 0144180

11. Fekonja A. Prevalence of dental developmental anomalies of permanent teeth in children and their influence on esthetics. J Esthet Restor Dent. 2017;1(8):1-8. http://dx.doi.org/10.1111/ jerd. 12302

12. Menini AAS, Silva MC, Iwaki LCV, Takeshita WM. Estudo radiográfico da prevalência de anomalias dentárias por meio de radiografias panorâmicas em diferentes faixas etárias. Rev Odontol UNICID. 2012;24(3):170-77.

13. Yassin SM. Prevalence and distribution of selected dental anomalies among Saudi children in Abha, Saudi Arabia. J Clin Exp Dent. 2016;8:485-90. http://dx.doi.org/10.4317/ jced. 52870

14. Torres PF, Simplício AHM, Luz ARCA, Lima MDM, Moura LFAD, Moura MS. Anomalias dentárias de número em pacientes ortodônticos. Rev Odontol UNESP. 2015;44(5):280-4. https:// doi.org/10.1590/1807-2577.0066

15. Pinheiro CC, Tostes MA, Pinheiro AR. Prevalência de anomalia dentária de número em pacientes submetidos a tratamento ortodôntico: um estudo radiográfico. Pesq Bras Odontoped Clin Integ. 2008;8(1):47-50. http://dx.doi.org/10.4034/1519 .0501 .2008 .0081 .0009

16. Scarpim MFPA, Nunes VS, Cerci BB, Azevedo LR, Tolazzi AL, Grégio AMT, et al. Prevalência de anomalias dentárias em pacientes avaliados para tratamento ortodôntico: estudo retrospectivo. Clin Pesq Odontol. 2006; 2(3):203-212. http:// dx.doi.org/10.7213/aor.v2i3.22948

17. Al-Abdallah MA, AlHadidi A, Hammad M, Al-Ahmad H, Salehe R. Prevalence and distribution of dental anomalies: A comparison between maxillary and mandibular tooth agenesis. Am J Orthod Dentofacial Orthop. 2015;148(5):7938. http://dx.doi.org/10.1016/j.ajodo.2015.05.024

18. Vastardis $H$. The genetics of human tooth agenesis: new discoveries for understanding dental anomalies. Am J Orthod Dentofacial Orthop. 2000;117(6):650-6.

19. Botero GE, Manco HA, Aguilar G, Castrillón L, Rendón JE, Marín ML. Retrospective study of dental anomalies and bone alterations of the jawbones in children 5 to 14 years old of the clinics of the Dental School, University of Antioquia. Rev Fac Odontol Univ Antioq. 2009;21(1):50-64.

20. Segundo AVL, Faria BLD, Silva UH, Vieira ITA. Estudo epidemiológico de dentes supranumerários diagnosticados pela radiografia panorâmica. Rev Cir Traumatol Buco-MaxiloFac. 2006;6(2):53-6. 
21. Albert G, Mondani PM, Parodi V. Eruption of supernumerary permanent teeth in a sample of urban primary school population in Genoa, Italy. Eur J Paed Dent. 2006;7:89-92.

22. Gupta SK, Saxena P, Jain S, Jain D. Prevalence and distribution of selected developmental dental anomalies in an Indian population. Sci. 2011;53(2):231-238. http://dx.doi. org/10.2334/josnusd.53.231

23. Fardi A, Kondylidou-Sidira A, Bachour Z, Parisis N, Tsirlis A. Incidence of impacted and supernumerary teeth-a radiographic study in a North Greek population. Med Oral Patol Oral Cir Bucal. 2011;16(1):56-61. http://dx.doi. org/10,4317/medoral.16.e56

24. Nolla CM. The development of the permanent teeth. ASDC J Dent Child. 1960;27(4):254-6.

25. Peck S, Peck L, Kataja M. Mandibular lateral incisor-canine transposition, concomitant dental anomalies, and genetic control. Angle Orthod. 1998;68(5):455-66. http://dx.doi.org/10. 1043/0003-3219 (1998) 068 <0455: MLICTC> 2.3.CO; 2

26. Armond MC, Saliba JHM, Silva VKS, Jaqueira F, Generoso LM, Ribeiro AR et al. Prevalência de alterações dentárias em crianças de 2 a 13 anos de idade em Três Corações, Minas Gerais, Brasil: estudo radiográfico. Pesqui Bras Odontopediatria Clin Integr. 2008;8(1):69-73. http://dx.doi.org/10.4034/1519.050 1.2008 .0081 .0013

27. Harris J, Whittington A. Dental neglect in children. Paediat Child Health. 2016;26(11):474-8. https://dx.doi.org/10.10 16/j.paed.2012.06.005

28. Bekiroglu N, Mete S, Ozbay G, Yalcinkaya S, Kargul B. Evaluation of panoramic radiographs taken from1,056 Turkish children. Niger J Clin Pract. 2015;18:8-12. http://dx. doi.org/10.4103/1119-3077.146965

29. Anitha RG, David MP. Prevalence of developmental dental anomalies - a clinical study. IJCMR. 2018;5(3):22-24. http:// dx.doi.org/10.1186/s12903-016-0236-6

Received on: 22/11/2018

Final version resubmitted on: 12/12/2019

Approved on: 12/2/2020 